\title{
Impact of Privatization on Lebanese Economy
}

\author{
Imad Farran Ahmad Abbas \\ School of Business, American University of Technology, Tyre, Lebanon
}

\begin{abstract}
Privatization of government services is the action that has been taken by local, state, and federal governments to allow private companies to offer their service instead. However, issues have aroused on the benefits and limitations of privatization on the well-being of its people. This study aimed at examining the impact of privatization on Lebanese economy. The paper will seek to answer if the Lebanese government can use this analogy to solve a plethora of issues that the economy is currently battling. The research used mixed method approach where data was collected following both qualitative and quantitative research strategies. A survey collecting data from the management of both privatized firms and government firms was used to come up with the results. The research also looked into the financial and operation performance of the already privatized firms to assess the performance over time. The telecommunication sector which was the first privatized industry is used as the benchmark of this study. The research found out that privatization is a double-edged sword that impacts the social wellbeing both positively and negatively. Regarding solving the ongoing financial and economic crisis, privatization seems to be an effective tool as it will reduce the administrative power of the management and thus lower the level of corruption in the economy which is one of the major contributions of the undergoing crisis.
\end{abstract}

Keywords: Privatization, Lebanon, Lebanese crisis, telecommunication sector

DOI: $10.7176 /$ JESD/12-8-06

Publication date: April $30^{\text {th }} 2021$

\subsection{Introduction}

With the current political surge and economic instability in Lebanon, questions of privatization have been rumoring around. The unprecedented economic and financial crisis is raising questions on whether privatization can be a remedy or not. Some scholars with little or no evidence to support their arguments are arguing that the privatization move will be beneficial to the economy. Those with the little evidence are arguing that the government has been so burdened to a point that it cannot manage some of the policies; a thing that privatization will look into and thus deliver the country out of the prevailing deadlock.

Over the years, we have seen privatization evolve from developed countries and being adapted by the developing countries. The move towards privatization started all the way in late 90s in England following the directive by the International Monetary Fund (IMF) and the World Bank when revising the terms of debt administration. According to Gray (1998), the IMF and the World Bank decided that for countries to be able to service their debts much easily, there was the need to restructure their economies to improve efficiency in terms of resource use.

The world Bank believes that the whole practice of privatization should develop a program surveys public sector projects, the associated problems and also classifies these projects according to the prevailing situation (Nellis \& Kikeri, 1989). For instance, Lebano is currently experiencing both economic and financial crisis (Baumann, 2019). There is a need to restructure the whole economy as per the IMF and World Bank suggestions such that the resources will be fully utilized and in the benefit of the economy

A decade or two after the developed economies came up with privatization, developing countries such Nigeria, Jordan, Kenya, Turkey, Egypt, Pakistan, Bangladesh among others are also following suite. Although Lebanon is yet to adapt this whole practice and put it into practice, some sectors in the economy have adopted the whole practice such as the Telecommunication sector. A decade after the country privatized the telecommunication sector, the economy grew in terms of employment opportunities, wage rates and also higher reproductivity (Ghaleb, 2001). Despite the economy setting a high foot on privatization in the first decade of $21^{\text {st }}$ century, little has been achieved and only a few sectors have been privatized which are not guaranteeing the economy's efficiency in terms of resource use and allocation.

Currently, Lebanon is facing an economic as well as financial crisis which as seen the Lebanese pound value depreciate in comparison to dollars. Initially, the value was capped at 1500 Lebanese pounds per dollar; However, with the crisis, the value of dollar has appreciated in terms of Lebanese pound from 1500 to round 11000 Lebanese pounds per dollar. This has resulted to emergence of black markets which are encouraging further upsurge of the situation (Baumann, 2019). This study therefore will aim at assessing the impact of privatization and look further into determining if the move towards privatization will make Lebanon country better by improving the economy at whole.

This article will serve to create a robust understanding of the term privatization and the privatization process. Notably, privatization can be classified into two; government and corporate. This study will look at the general 
form of privatization and which mostly refers to the transfer of government resources to private firms. This study will however look into various methods of privatization and which would be applicable to Lebanese economy.

The broad objective of the study will be to understand what privatization is and the impact that it can have on the Lebanese economy. The study will also assess the impact that the already privatized sectors have on the whole Lebanese economy. The study will also assess if privatization will better the deadlock Lebanese economy. The literature review will cover the privatization concept as defined by various scholars, the types of privatization and also the impact of privatization in different economies of developing countries. Both qualitative and quantitative research strategies will be used in this study. The research will utilize a survey method where a questionnaire will be used to collect data. Both Excel and SPSS software will be used to analyze the already collected data.

\subsection{Literature Review}

Privation has been a growing concern especially with economies from developing countries. With the previous studies conducted on privatization, little was known especially on the impacts of this practice. Privatization was introduced in 90s among economies of developed countries and its wave has spread to the developing countries. In this section, I will address what scholars' term as privatization, the various methods and the impacts of privatization. The study will help relate these impacts to a conceptual understanding of the economy.

\subsection{Definition of Privatization}

According to Beverlin (2019), privatization refers to methods by which governments outsource formerly publicly provided services. In his study, Beverlin argues that privatization exist on a continuum ranging from the complete takeover of what was once deemed as public and what was previously funded by a collective account to private firms. His study found out that managers utilize privatization as an administrative tool by which they control the price and cost of governance. The author further investigates the arguments for privatization which he bases on one concept of taxpayers' burden. He argues that privatization most often focuses on the potential cost savings to the taxpayers. The author however does not come out clearly on the exact definition of the term privatization and also does not mention how this practice would affect an economy.

In his study on privatization policies and development, Hansen (2016) explains the history of privatization in Europe when the government contracted public services to the private sector. Hansen argues that privatization emerged after the private individuals and companies started taking the majority of functions and services including tax collection, army supplies, religion and even construction. In explaining the history of privatization in Greece, the author cites a situation when Troika forced the Greece government to sell its public enterprises and earn 50 million euros. Although this move was strongly blocked by labor unions and political opposition team, it was termed as privatization. In his study, the author presents an understanding of privatization from several countries' perspective. Although the author details some historical aspect of the term, he does not clearly detail what this term is and what it means directly.

According to Boubakri and Saffar (2019), Privatization involves the sale of government state-owned enterprises and assets to private economic agents. In their article, the authors seek to determine the link between the level of state ownership in the Newly privatized firms and their level of debt in a country setting. The author further states that under government ownership, the firms receive support from the government such as bank financing and also regulatory control. However, according to the authors, such support reduces the firm's incentive to maximize incentives.

\subsection{Impact of Privatization}

According to Johnson (2014), the service needs of individuals create employment opportunities in both formal sectors but working in public has been considered to have more benefits such as better wages and secure retirements than the other. Therefore, it facilitates the reduction of people in poverty-level jobs by moving them towards the middle-class. However, the decisions made by the governments to outsource its services has come with various challenges. This is due to reduction of wages and little benefits that accompany it. According to the author, the private sector claim to have the capacity to run public services better, faster, and at a lower price and on the other hand, the government intends to reduce its spending through privatization of its services. Unfortunately, the cost will not be more economical as intended. Instead, it becomes higher indirectly. According to his research, Johnson (2014) found out that privatization led to a decline in the middle class and rise in povertylevel jobs. Thus, it worsens the current level of economic inequality. Furthermore, it increases budgeting stress of the local, state and federal governments.

According to a study conducted by Aminu and Peterside (2014) seeking to determine the impact of privatization on the power sector in Nigeria, the researchers argued that this form of privatization in this country was based on ideology, capitalistic theories, assumptions and orientations. The authors further stated that supposition of unrestricted market actually has presupposition that the market will be operating in an environment that is highly competitive. In contrary to the authors, the authors found out that privatization of power in Nigeria 
had created social classes where only a few people became rich while the rest were entrenched in poverty and work. The authors also found out that privatization had led to an increase in the amount of tax payable to the government. The researchers concluded by recommending that there should be a plan after privatization which seeks to balance the situation without leaving the people worse off while making others better.

Lowe (2014) studied the impact of privatization of railway transport in the Sub-Saharan Africa. In his study, Lowe utilized the novel spatial data set and the light density was measured using satellites at night. Based on his findings, privatization brought along a positive impact especially in the localized Sub-Saharan Africa economies. The author concluded that there was a need to restructure and reform railway transport if it was to be considered as a profitable venture even after being privatized as it was declining due to mismanagement.

In 2015, Omran studied the consequences on performance after privatization of State-Owned Enterprises (SOE) in Egypt. In his study, he assessed the performance of the recently privatized enterprises in Egypt and determined if there was a significant difference in the performance after the new ownership structure. He further investigated the financial and operation impact that this privatization brought in the ownership structure. His research found out that privatization brought along an increase in the profits realized, capital expenditures and the dividends and also that the operating efficiency was also high. However, he noted that privatization also brought along a decrease in the employment levels and that the risks had increased.

In 2015, Abramovitz and Zelnick (2015) examined the impact of privatization on human services. Their research sought to determine the implications of human resource direct practice. In their study, they reviewed the core responsibilities of the state alongside citing three historical stages of privatization. The researchers further explored what impact privatization brought to the service industry. The authors concluded that there was a need to formulate steps that would help social workers to adapt to the plethora of changes that they experienced in their profession.

Pagano et al. (2013) in their research examined what impact privatization brought towards efficiency and effectiveness of ports performance in USA and Panama. The authors used a financial econometric approach where they evaluated how the ports were performing when controlled by the government and also when under the control of private firms. Their results showed that there was a plethora of gains after privatization depicted by a reduction in the cost of operations as well as an improvement in the service structures. The authors concluded that the results of privatization would be different depending on the extent and the degree of privatization.

\subsection{Methodology}

This study was performed in Lebanon among the privatized telecommunication sector and others and the government entities yet to undergo this change of ownership. The study considered the telecommunication sector of Lebanon as it is the well-known industry which adopted this practice in the late $90 \mathrm{~s}$ and can be in a position to be reviewed in terms of changes. Non-privatized industries in the Lebanese economy include Beirut, Sidon, Tripoli ports among others including an Intra Investment Company. The study thus sought to determine the performance of these industries by questioning various leaders who were at the level of management either before or after privatization. Data on the financial and operational performance of various sector before and after privatization was also collected and analyzed to measure the nature of impact that privatization has on Lebanese economy and how this can be used to solve the plethora of issues surrounding the economy. This data was captured mostly through a survey as well as looking into the performance from a qualitative review.

\subsection{Results and Discussions}

This study sought to determine the overall impact that privatization has on the Lebanese economy. The study sought to determine this overall effect from all the four general sectors that make up an economy and which include primary, secondary, tertiary, and quaternary sectors. The research first sought to determine the process of privatization in Lebanon since 90 s and the plans. Below is table 1 showing the privatization plan over the years. 
Table 1 showing the privatization process and plan in Lebnonon

\begin{tabular}{|c|c|c|}
\hline Sector & Characteristics and plan & Timetable \\
\hline Energy & $\begin{array}{l}\text { The Lebanese government sought to privatize } \\
\text { seven thermal \& hydraulic power plants. These } \\
\text { plants generated around } 1,244 \text { megawatts of power } \\
\text { and which was sufficient for } 90 \% \text { of population } \\
\text { needs. The biggest plants being privatized included } \\
\text { Jiye \& Zouk producing } 80 \% \text { of electricity. }\end{array}$ & $\begin{array}{l}\text { The law ratified the plan by the } \\
\text { Lebanese government in } \\
\text { September } 2002 \text { to sell forty } \\
\text { percent of production and } \\
\text { distribution power. }\end{array}$ \\
\hline Water & $\begin{array}{l}\text { The Lebanese government also sought to eighty- } \\
\text { five water departments to provide water all over } \\
\text { the country. }\end{array}$ & $\begin{array}{l}\text { This privatization deal was signed } \\
\text { and given a formal consent in May, } \\
\text { 2002. The Water management in } \\
\text { Tripoli contracted to French } \\
\text { company }\end{array}$ \\
\hline Oil refineries & $\begin{array}{l}\text { This privatization is non-operating currently. } \\
\text { However, it still has } 500 \text { employees enrolled. The } \\
\text { plan sought to privatize two oil refineries which are } \\
\text { Zahrani, producing } 21,000 \text { barrels per day and } \\
\text { Tripoli producing } 5,000 \text { barrels per day }\end{array}$ & $\begin{array}{l}\text { This law is still under } \\
\text { consideration. }\end{array}$ \\
\hline $\begin{array}{l}\text { Telecommunication } \\
\text { sector }\end{array}$ & $\begin{array}{l}\text { The law sought to privatize the telecommunication } \\
\text { sector with } 1.5 \text { million fixed lines accounting to } \\
\text { forty percent of the population. This was to be } \\
\text { achieved through a contractual agreement between } \\
\text { private companies \& government to run mobile. } \\
\text { By then, Lebanon had more than } 600,000 \text { mobile } \\
\text { subscribers. }\end{array}$ & $\begin{array}{l}\text { The law was ratified by } 2002 \text { and a } \\
\text { massive auctioning happened till } \\
\text { end } 2002 \text { to get bids for mobile } \\
\text { operators. }\end{array}$ \\
\hline Postal services & $\begin{array}{l}\text { The law sought to privatize the postal services } \\
\text { which had more than one thousand, one hundred } \\
\text { employees. }\end{array}$ & $\begin{array}{l}\text { A contractual agreement happens } \\
\text { between private companies and the } \\
\text { government and hence the law } \\
\text { ratified this practice. }\end{array}$ \\
\hline $\begin{array}{l}\text { Transportation } \\
\text { (Middle-East } \\
\text { Airlines) }\end{array}$ & $\begin{array}{l}\text { This Airline was owned by the Central Bank of } \\
\text { Lebanon. The company was experienced a loss of } \\
\$ 100 \text { million per year up until } 2002 \text { when it was } \\
\text { expected to break even. Initially, there were } 4500 \\
\text { employees who reduced to } 3300 \text { only. There was } \\
\text { also an upgrade of bus terminals and fleets. The } \\
\text { government sought to privatize this company }\end{array}$ & $\begin{array}{l}\text { This ruling is awaiting favorable } \\
\text { market conditions }\end{array}$ \\
\hline Airports and ports & $\begin{array}{l}\text { The capacity increased to handle } 6 \text { million users. } \\
\text { This has led to rehabilitation of various terminuses } \\
\text { including the one at Queleiat airport }\end{array}$ & $\begin{array}{l}\text { The study on whether to privatize } \\
\text { this sector are still underway and } \\
\text { awaiting to be submitted to the } \\
\text { higher privatization council of } \\
\text { Lebanon. }\end{array}$ \\
\hline
\end{tabular}

Source ("crisis through privatisation | Social Watch", 2021)

Using the telecommunication sector which has already undergone complete metamorphosis of privatization, the study found out that privatization in the case of the fast-growing telecommunication sector has been having a positive impact which is reflected in the high wage rate, creation of jobs and hence reduction of unemployment levels and also an increase in the level of productivity. The research found out that new jobs were created in the long run following the inception and start of the Liban telecommunication network. This also suggested that there would be a massive expansion in the telecommunication network and the only payment that the government might be prompted to offer if this happens is a golden handshake.

According to the study, privatizing telecommunication network has been so beneficial to both to the buyer and the seller and more to the latter when the former undertakes the process in stages appreciating the value of the divested asset. The research also found out that the big winner of privatization is always the economy as a whole which comprises of the Lebanese consumer. As aforementioned, the research further found out that privatization tends to reduce the administrative controls that a manger has and hence improves on the transparency. This transparency is reflected in the efficient use of public resources.

After a further analysis on various companies in Lebanon and how long they have been privatized, the study found out that $20 \%$ of them have been privatized for $0-4$ years, $45 \%$ have been privatized for $4-8$ years, $30 \%$ have been privatized for 8-12 years with the rest having been privatized for more than 12 years. After the analysis and the changing world and technologically developing world, it emerges that Lebanon is lagging behind in terms of 
privatization. Within the last four years, the country has only privatized $20 \%$ of the companies. This is the period that the economy is undergoing financial crisis which suggests that lack of privatization in this evolving world can be one of the causes of this financial and operation crisis. Figure 1 below shows the analysis

Figure 1 showing the duration of time various companies have been privatized

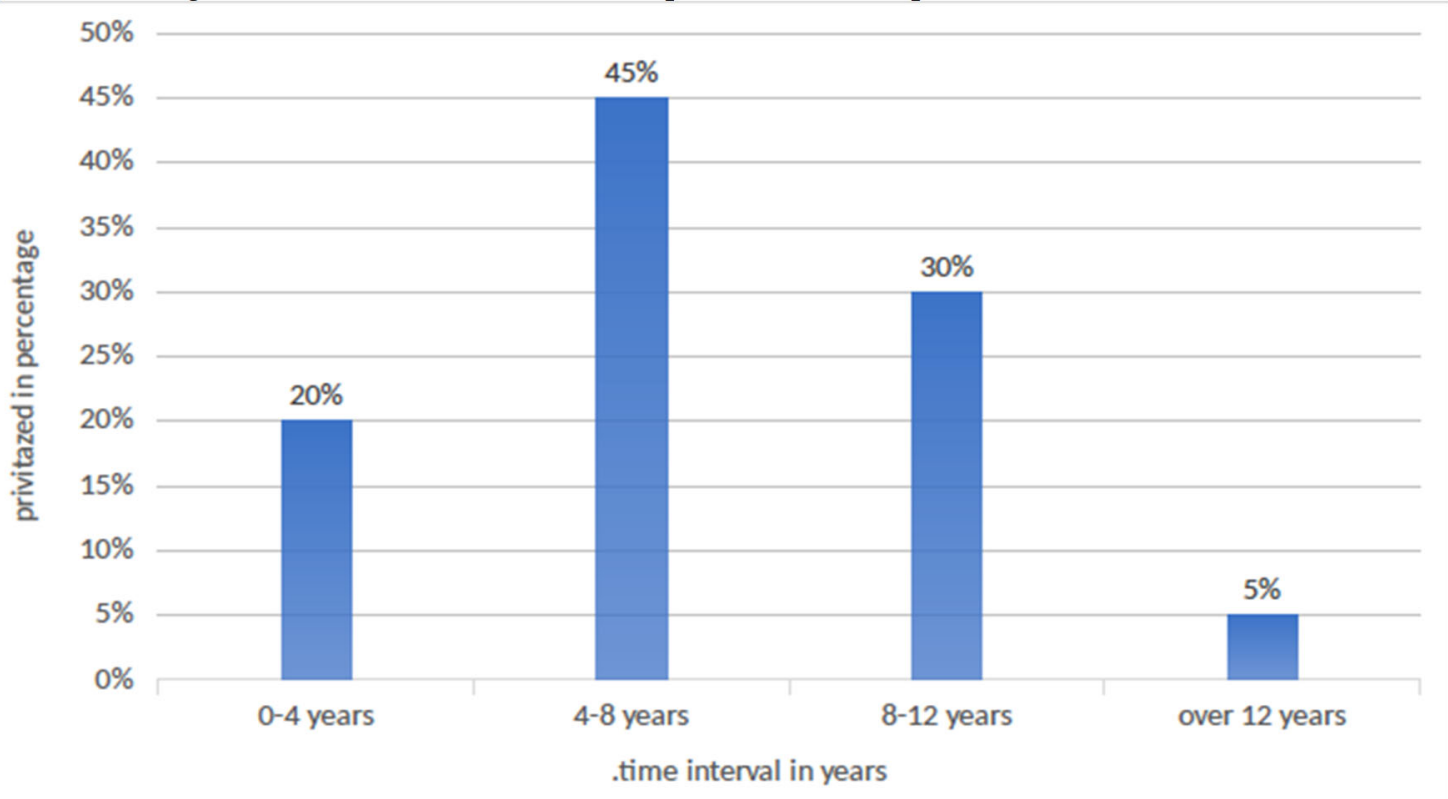

(Source: Authors own research)

To understand the impact of privatization on the economy, managers and other respondents selected for this study were requested to rate the extent to which privatization affected profitability of the organizations they worked for or managed. A total number of 30 respondents were considered. Below is a table showing the analysis of the type of area that experienced a positive change versus the respondents rating and their corresponding cumulative frequencies. From the results, it is clear that privatization would bring better than harm to an economy owing to over $80 \%$ acknowledgement from the relevant authorities and stakeholders. Besides, this is in line with the study conducted by Steel and Heald (1984) among other researchers and scholars.

\begin{tabular}{|l|l|l|l|l|l|l|}
\hline Type of Area & Agree & \multicolumn{2}{l|}{ Not agree } & \multicolumn{2}{l|}{ Unaware } \\
\cline { 2 - 7 } & $\begin{array}{l}\text { No of } \\
\text { respondents }\end{array}$ & $\begin{array}{l}\% \text { Cumulative } \\
\text { frequency }\end{array}$ & $\begin{array}{l}\text { No of } \\
\text { respondents }\end{array}$ & $\begin{array}{l}\% \\
\text { Cumulative } \\
\text { frequency }\end{array}$ & $\begin{array}{l}\text { No } \\
\text { respondents }\end{array}$ & $\begin{array}{l}\text { Cumulative } \\
\text { frequency }\end{array}$ \\
\hline $\begin{array}{l}\text { Share } \\
\text { ownership } \\
\text { area }\end{array}$ & 24 & 80.0 & 4 & 13.33 & 2 & 6.67 \\
\hline $\begin{array}{l}\text { Managerial } \\
\text { ownership }\end{array}$ & 26 & 86.67 & 1 & 3.333 & 3 & 10.00 \\
\hline $\begin{array}{l}\text { Development } \\
\text { policies }\end{array}$ & 28 & 93.33 & 0 & 0.00 & 2 & 6.67 \\
\hline
\end{tabular}

\section{Conclusion}

In conclusion, the study found out that that the most significant effects of privatization on profitability of organizations were that; under private ownership, managers face stronger incentives to reduce costs and to innovate. Because of the higher incentives to innovate and to save costs, the company now has higher profits, and that privatization reduced political interests in the firm, and that privatization helped reduce worker crowding in the firm respectively. This means that, with the current ongoing financial and operational crisis in Lebanon, privatization would be a good idea as it will ensure that resources are fully, efficiently and also economically used and hence reducing wastage. Privatization will also reduce the administrative controls of managers who mostly are politicians and who take the chance to root public resources thus worsening the economy. By reducing the administrative tools of these managers, chances and holes of embezzlement will reduce and in the long run, the economy will return to its normalcy. One limitation that this study did not look into much is the effect of privatization on labor market and how privatization can improve competitiveness in the industry. Notably, this concept can cover so many aspects but I would be interested to learn the above or study the above in a future study. 


\section{References}

Abramovitz, M. and Zelnick, J. (2015). Privatization in the Human Services: Implications for Direct Practice. Clinical Social Work Journal, 43(3), pp.283-293

Aminu, I. and Peterside, Z. (2014). The Impact of Privatization of Power Sector in Nigeria: A Political Economy Approach. Mediterranean Journal of Social Sciences.

Baumann, H. (2019). The Causes, Nature, and Effect of the Current Crisis of Lebanese Capitalism. Nationalism And Ethnic Politics, 25(1), 61-77. https://doi.org/10.1080/13537113.2019.1565178

Beverlin, R. M. (2019). Privatization. Salem Press Encyclopedia.

Boubakri, N., \& Saffar, W. (2019). State Ownership and Debt Choice: Evidence from Privatization. Journal of Financial \& Quantitative Analysis, 54(3), 1313-1346. https://doiorg.ezproxy.bellevue.edu/10.1017/S0022109018000881

Confronting the fiscal crisis through privatisation | Social Watch. Socialwatch.org. (2021). Retrieved 15 March 2021, from https://www.socialwatch.org/node/10841.

Estrin, S., \& Pelletier, A. (2018). Privatization in Developing Countries: What Are the Lessons of Recent Experience?. The World Bank Research Observer, 33(1), 65-102. https://doi.org/10.1093/wbro/lkx007

Gray, M. (1998). Economic reform, privatization and tourism in Egypt. Middle Eastern Studies, 34(2), 91-112. https://doi.org/10.1080/00263209808701224

Hansen, A. (2016). Privatization : Policies, Developments and Challenges. Nova Science Publishers, Inc.

Joey, G. (2001). The Lebanese Telecommunication Sector and The Impact of Privatization on The Labor Market. Economic Research Forum, Working Papers.

Johnson, D. (2014). How Government "Contracting Out" Drives Up Costs, Pushes Down Workers | OurFuture.org by People's Action. OurFuture.org by People's Action. Retrieved 15 March, 2021, from https:// ourfuture.org/20140604/governmentcontracting-out-costs-more-than-it-saves-hurts-people

Lowe, M. (2014). Rail Revival in Africa? The Impact of Privatization. Macroeconomic Challenges Facing LowIncome Countries, 1(1).

Nellis, J., \& Kikeri, S. (1989). Public enterprise reform: Privatization and the World Bank. World Development, 17(5), 659-672. https://doi.org/10.1016/0305-750x(89)90066-

Omran, M. (2015). Performance Consequences of Privatizing Egyptian State-Owned Enterprises: The Effect of Post-Privatization Ownership Structure on Firm Performance. Multinational Finance Journal, 8(1/2), pp.73114.

Pagano, A., Wang, G., Sánchez, O. and Ungo, R. (2013). Impact of privatization on port efficiency and effectiveness: results from Panama and US ports. Maritime Policy \& Management, 40(2), pp.100-115.

Steel, D. R., \& Heald, D. (1984). Privatizing public enterprises: options and dilemmas. Royal Institute of Public Administration. 